\title{
PREVALENSI ANEMIA PADA PASIEN GAGAL JANTUNG DI RSUP PROF. DR. R. D. KANDOU MANADO PERIODE 2013
}

\author{
${ }^{1}$ Aaron Ch. Rambi \\ ${ }^{2}$ Linda W. A. Rotty \\ ${ }^{2}$ Agnes L. Panda
}

\author{
${ }^{1}$ Kandidat Skripsi Fakultas Kedokteran Universitas Sam Ratulangi Manado \\ ${ }^{2}$ Bagian Ilmu Penyakit Dalam Fakultas Kedokteran Universitas Sam Ratulangi \\ Manado \\ Email: aaron.rambi@yahoo.com
}

\begin{abstract}
Anemia is common in heart failure patients, especially in patients with old age, female, chronic kidney disease, ACE inhibitors (angiotensin-converting-enzyme inhibitors) users and in patients with severe congestive heart failure. Anemia is an independent prognostic factor for mortality. Anemia is characterized by the value of hemoglobin less than $13 \mathrm{~g} \mathrm{/} \mathrm{dl}$ in men and less than $12 \mathrm{~g} / \mathrm{dl}$ in women. The purpose of this study was to determine the prevalence of anemia in patients with heart failure. This was a descriptive retrospective study. The samples of this study were 834 medical records of hospitalization and ambulatory patients in RSUP Prof. Dr. R. D. Kandou Manado which had hematology examination results in 2013. The results showed that the prevalence of anemia in heart failure patients was $33.6 \%$ and mostly were mild anemia (57\%). Although not so significant, the proportion of female patients with anemia were higher (33,57\%) than male (33,54\%). The over 64 years group has the highest proportion of all age groups. Conclusion: Anemia is common in heart failure patients, especially those aged over 64 years. There was no significant difference between the proportion of women and men who were anemic. Most patients suffered from mild anemia.
\end{abstract}

Keywords: anemia, heart failure, prevalence

\begin{abstract}
Abstrak: Anemia sering ditemukan pada gagal jantung terutama pada pasien yang berusia tua, dengan jenis kelamin perempuan, menderita kelainan ginjal kronik, pengguna ACE inhibitor (angiotensin-converting-enzyme inhibitor) dan pada pasien dengan gagal jantung kongestif yang parah. Anemia merupakan faktor prognostik independen terhadap kematian. Anemia ditandai dengan nilai hemoglobin kurang dari 13 g/dl pada laki-laki dan kurang dari 12 g/dl pada perempuan. Tujuan penelitian ini adalah untuk mengetahui prevalensi anemia pada pasien gagal jantung. Penelitian ini bersifat deskriptif retrospektif. Sampel penelitian ini adalah 834 rekam medis pasien rawat inap dan rawat jalan di RSUP Prof. Dr. R. D. Kandou Manado yang memiliki hasil pemeriksaan hematologi. Hasail penelitian menunjukkan bahwa prevalensi anemia pada pasien gagal jantung adalah 33,6\% dan sebagian besar menderita anemia ringan (57\%). Walaupun tidak begitu signifikan, proporsi dari pasien perempuan dengan anemia lebih tinggi (33,57\%) dibandingkan pria (33,54\%). Kelompok umur lebih dari 64 thun memiliki proporsi tertinggi dibadingkan semua kelompok umur. Simpulan: Anemia sering ditemukan pada pasien gagal jantung, terutama yang berusia lebih dari 64 tahun. Tidak ada perbedaan yang signifikan antara proporsi dari peremuan dan laki-laki yang menderita anemia. Kebanyakan pasien menderita anemia ringan.
\end{abstract}

Kata kunci: anemia, gagal jantung, prevalensi 
Sekitar 5,1 juta orang Amerika yang berumur $\geq 20$ tahun mengidap gagal jantung. Pada tahun 2030, diperkirakan prevalensi dari gagal jantung akan meningkat sebanyak 25\% dari perkiraan di tahun 2013. ${ }^{1}$

Riset Kesehatan Dasar Nasional 2013 menyebutkan prevalensi penyakit gagal jantung di Indonesia sebesar 0,3\%. Provinsi dengan prevalensi gagal jantung tertinggi ditempati oleh Nusa Tenggara Timur dengan 0,7\%, sedangkan Sulawesi Utara menempati posisi keempat dengan $0,4 \%{ }^{2}$

Anemia pada gagal jantung sering ditemukan pada pasien yang berusia tua, dengan jenis kelamin perempuan, menderita kelainan ginjal kronik, ${ }^{3,4}$ mengalami penurunan indeks massa tubuh, pengguna ACE (angiotensin-convertingenzyme) inhibitor, pasien dengan peningkatan tekanan jugular vena, pasien dengan edema ekstremitas bawah, ${ }^{4}$ pada pasien dengan hipertensi, ${ }^{3}$ dan pada pasien dengan gagal jantung kongestif yang parah. $^{5}$

Anemia merupakan faktor prognostik independen terhadap kematian pada pasien gagal jantung. ${ }^{3}$ Penelitian menunjukkan terdapat peningkatan angka mortalitas dan morbiditas pada pasien gagal jantung tingkat menengah sampai berat dengan penurunan hemoglobin lebih dari 12 bulan. $^{6}$

Beberapa peneliti berpendapat, peningkatan kadar hemoglobin pada pasien gagal jantung bukan saja dapat menurunkan angka mortalitas dan morbiditas, ${ }^{5-8}$ tetapi juga meningkatkan kualitas hidup. ${ }^{7}$

Berdasarkan pernyataan-pernyataan di atas maka penulis tertarik dalam mengambil judul "prevalensi anemia pada pasien gagal jantung di RSUP Prof. Dr. R. D. Kandou Manado periode 2013”.

\section{METODE PENELITIAN}

Penelitian ini bersifat deskriptif retrospektif. Penelitian dilakukan di bagian catatan rekam medik bagian/ SMF Ilmu Penyakit Dalam dan bagian kardiologi FK UNSRAT RSUP Prof. Dr. R. D. Kandou
Manado pada bulan November 2014 sampai Desember 2014.

Penelitian ini menggunakan rekam medis sebagai data sekunder dengan subjek penelitian adalah data pasien yang telah didiagnosis gagal jantung baik yang dirawat inap dan dirawat jalan di bagian Kardiologi dan Divisi Kardiologi Departemen / SMF Ilmu Penyakit Dalam FK UNSRAT BLU RSUP Prof. Dr. R. D. Kandou Manado yang melakukan pemeriksaan hematologi pada bulan Januari 2013 - Desember 2013. Kriteria eksklusi pada penelitian ini adalah pasien dengan perdarahan, keganasan hematologi, pasien dengan anemia aplastik.

\section{HASIL PENELITIAN \\ Karakteristik Umum Pasien Gagal Jantung}

Sampel penelitian adalah 894 data rekam medis pasien gagal jantung yang memiliki hasil laboratorium pemeriksaan hematologi pada bulan Januari 2013 sampai Desember 2013. Sampel penelitian terdiri atas 144 data pasien rawat inap dan 750 data pasien rawat jalan.

Tabel 1. Jumlah dan Persentase Jenis Kelamin Pasien Gagal Jantung

\begin{tabular}{lll}
\hline Jenis kelamin & Jumlah & Persentase (\%) \\
\hline Laki - laki & 480 & 53,7 \\
Perempuan & 414 & 46,3 \\
\hline Total & 894 & 100 \\
\hline
\end{tabular}

Berdasarkan jenis kelamin, sampel terbagi menjadi $480(53,7 \%)$ orang laki laki dan 414 (46,3\%) orang perempuan.

Tabel 2. Jumlah dan Persentase Kelompok Umur Pasien Gagal Jantung

\begin{tabular}{cccc}
\hline Pasien & \multicolumn{2}{c}{ Jenis kelamin } & Total \\
\cline { 2 - 3 } gagal \\
\cline { 2 - 3 } & $\mathrm{L}$ & $\mathrm{P}$ & \\
\hline $\begin{array}{c}\text { Anemia } \\
\text { Tidak }\end{array}$ & 161 & 139 & 300 \\
$\begin{array}{c}\text { anemia } \\
\text { Total }\end{array}$ & 319 & 275 & 594 \\
\hline & 480 & 414 & 894
\end{tabular}


Usia rata - rata pasien ialah 61,69 tahun dengan usia tertua ialah 92 tahun dan usia terendah ialah 13 tahun. Usia pasien kemudian dibagi menjadi 4 kelompok umur, yaitu kurang dari 25 tahun, 25 - 44 tahun, 45 - 64 tahun dan lebih dari 64 tahun. Menurut kelompok umur, terdapat 422 orang $(47,2 \%)$ penderita gagal jantung yang termasuk dalam kelompok umur $>64$ tahun, 369 orang $(41,3 \%)$ pada kelompok umur 45 - 64 tahun, 80 orang (8,9\%) pada kelompok umur 25 - 44 tahun dan 23 orang $(2,6 \%)$ pada kelompok umur $<25$ tahun.

\section{Prevalensi Anemia Pada Gagal Jantung}

Tabel 3. Jumlah dan Persentase Anemia pada Pasien Gagal Jantung

\begin{tabular}{ccc}
\hline $\begin{array}{c}\text { Pasien } \\
\text { gagal } \\
\text { jantung }\end{array}$ & Jumlah & Persentase (\%) \\
\hline $\begin{array}{c}\text { Anemia } \\
\text { tidak } \\
\text { anemia }\end{array}$ & 300 & 33,6 \\
\hline Total & 594 & 66,4 \\
\hline
\end{tabular}

Berdasarkan hasil pemeriksaan hematologi pada sampel, nilai rata-rata hemoglobin sebesar 12,888 g/dl. Nilai hemoglobin tertinggi sebesar $24 \mathrm{~g} / \mathrm{dl}$ sedangkan yang terendah sebesar $3,4 \mathrm{~g} / \mathrm{dl}$. Dari 894 sampel, terdapat 300 pasien (33,6\%) yang menderita anemia dan 594 pasien (66,4\%) yang tidak menderita anemia. Dari 300 pasien anemia, 65 diantaranya adalah pasien rawat inap dan 235 orang lainnya adalah pasien rawat jalan.

Tabel 4. Distribusi Anemia pada Pasien Gagal Jantung Berdasarkan Jenis kelamin

\begin{tabular}{lll}
\hline $\begin{array}{l}\text { Kelompok } \\
\text { Umur }\end{array}$ & Jumlah & Persentase \\
\hline$<25$ tahun & 23 & 2,6 \\
$25-44$ tahun & 80 & 8,9 \\
$45-64$ tahun & 369 & 41,3 \\
$>64$ tahun & 422 & 47,2 \\
\hline Total & 894 & 100,0 \\
\hline
\end{tabular}

Jumlah pasien gagal jantung dengan jenis kelamin laki-laki ialah 480 orang dan yang menderita anemia ialah 161 orang, sedangkan jumlah pasien gagal jantung dengan jenis kelamin perempuan ialah 414 orang dan yang menderita anemia ialah 139 orang.

Tabel 5. Tabel Distribusi Pasien Gagal Jantung yang mengalami anemia dan tidak anemia berdasarkan Kelompok Usia

\begin{tabular}{|c|c|c|c|c|c|}
\hline \multirow[b]{2}{*}{$\begin{array}{c}\text { Pasien } \\
\text { gagal } \\
\text { jantung }\end{array}$} & \multicolumn{4}{|c|}{ Kelompok Usia } & \multirow[b]{2}{*}{ Total } \\
\hline & $\begin{array}{l}<2 \\
5\end{array}$ & $\begin{array}{l}25 \\
- \\
44 \\
\end{array}$ & $\begin{array}{l}45 \\
-64\end{array}$ & $>64$ & \\
\hline Anemia & 8 & 18 & $\begin{array}{l}10 \\
6\end{array}$ & 168 & 300 \\
\hline $\begin{array}{c}\text { Tidak } \\
\text { Anemia }\end{array}$ & 15 & 62 & $\begin{array}{l}26 \\
3\end{array}$ & 254 & 594 \\
\hline Total & 23 & 80 & $\begin{array}{l}36 \\
9\end{array}$ & 422 & 894 \\
\hline
\end{tabular}

Berdasarkan kelompok umur, ditemukan 8 orang pada kelompok usia $<24$ tahun, 18 orang pada kelompok usia 25 44 tahun, 106 orang pada kelompok usia 45 - 64 tahun dan 168 orang pada kelompok usia $>64$ tahun menderita anemia.

Tabel 6. Derajat Anemia Pada Pasien Gagal Jantung dengan Anemia

\begin{tabular}{ccc}
\hline Derajat Anemia & Jumlah & $\begin{array}{c}\text { Persentase } \\
\text { (\%) }\end{array}$ \\
\hline Ringan & 171 & 57,0 \\
Sedang & 106 & 35,3 \\
Berat & 23 & 7,7 \\
Total & 300 & 100 \\
\hline
\end{tabular}

Derajat anemia ditentukan berdasarkan kriteria WHO yaitu disebut ringan apabila $\mathrm{Hb}>10 \mathrm{gr} / \mathrm{dl}$, sedang apabila $\mathrm{Hb} 7-10$ gr/dl dan berat apabila $\mathrm{Hb}<7$ gr/dl. Berdasarkan kriteria tersebut, ditemukan 171 (57\%) sampel mengalami anemia ringan, 106 (35,3\%) anemia sedang, 23 (7,7\%) anemia berat.

Berdasarkan data yang tersedia, terdapat sembilan belas pasien dari dua ratus tiga puluh delapan pasien anemia pada sampel yang memiliki data mean 
corpuscular volume (MCV),mean corpuscular hemoglobin $(\mathrm{MCH})$ dan mean corpuscular hemoglobin concentration (MCHC). Berdasarkan nilai MCV ditemukan mikrositer berjumlah 8 orang, normositer berjumlah 9 orang dan makrositer berjumlah 2 orang. Berdasarkan nilai MCH ditemukan 6 pasien hipokromik dan 11 pasien normokromik

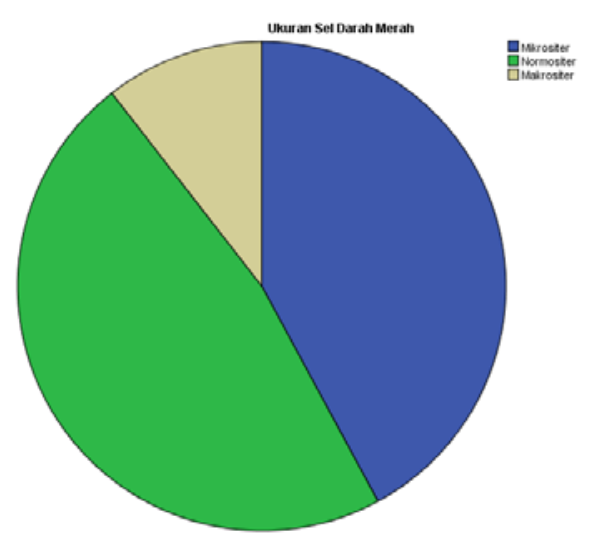

Gambar 4.B.3. Ukuran Sel Darah Merah Pada Pasien Gagal Jantung dengan Anemia

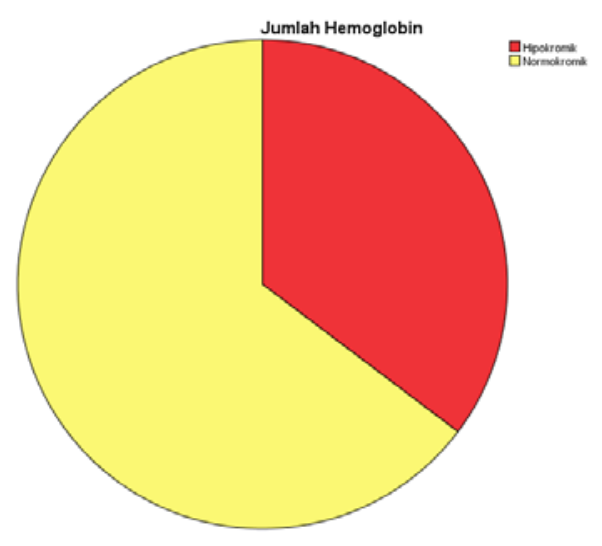

Gambar 4.B.4. Jumlah Hemoglobin Dari Sel Darah Merah Pada Pasien Gagal Jantung dengan Anemia

\section{BAHASAN}

Anemia didefinisikan sebagai penurunan jumlah massa eritrosit (red cell mass) sehingga tidak dapat memenuhi fungsinya untuk membawa oksigen dalam jumlah yang cukup ke jaringan perifer (penurunan oxygen carrying capacity). Keadaan anemia salah satunya dapat ditunjukkan oleh penurunan kadar hemoglobin. ${ }^{9}$ Nilai hemoglobin pada anemia bervariasi, penelitian ini menggunakan kriteria anemia yang digunakan oleh WHO yaitu laki-laki $<13$ g/dl dan perempuan $<12$ g/dl. ${ }^{9}$ Pada penelitian ini dari 894 pasien gagal jantung yang dirawat inap dan dirawat jalan di RSUP Prof. Dr. R. D. Kandou pada Januari 2013 - Desember 2013, terdapat 300 pasien (33,6\%) yang menderita anemia, 65 diantaranya adalah pasien rawat inap dan 235 orang lainnya adalah pasien rawat jalan.

Menurut jenis kelamin, pasien dengan gagal jantung lebih banyak berjenis kelamin laki - laki yaitu 480 pasien dibandingkan dengan perempuan yang berjumlah 414 orang. 161 pasien dari 480 pasien laki - laki yang didiagnosis gagal jantung menderita anemia (33,54\%), sedangkan 139 pasien dari 414 pasien perempuan yang didiagnosis gagal jantung menderita anemia (33,57\%). Hal ini sesuai dengan pernyataan dari Yi-Da Tang dan Stuart D. Katz ${ }^{4}$ yang menyebutkan jenis kelamin perempuan merupakan salah satu karakteristik klinik yang berhubungan dengan peningkatan resiko anemia pada gagal jantung.

Berdasarkan kelompok umur, pasien gagal jantung dibagi menjadi 4 kelompok umur yaitu kurang dari 25 tahun, 25 - 44 tahun, 45 - 64 tahun dan lebih dari 64 tahun. Kelompok umur terbanyak ialah $>64$ tahun dengan 422 pasien. 8 dari 23 (34,7\%) pasien kelompok usia $<25$ tahun, 18 dari 80 (22,5\%) pasien kelompok usia 25 - 44 tahun, 106 dari 369 (28,72\%) pasien kelompok usia 45 - 64 tahun dan 168 dari 422 (39,81\%) pasien kelompok usia >64 tahun menderita anemia. Proporsi penderita anemia pada pasien gagal jantung berusia $>64$ tahun lebih besar dibanding kelompok umur lainnya. Hal ini sesuai dengan pernyataan Yi-Da Tang dan Stuart D. Katz ${ }^{4}$ yang menyebutkan peningkatan usia merupakan salah satu karakteristik klinik yang berhubungan dengan peningkatan resiko anemia pada gagal jantung.

Berdasarkan derajat anemia menurut $\mathrm{WHO}^{10}$ ditemukan kebanyakan sampel 
penelitian mengalami anemia ringan 171 (57\%), sementara anemia sedang 106 (35,3\%) sampel dan $23(7,7 \%)$ sampel mengalami anemia berat.

Berdasarkan sembilan belas data pasien yang memiliki mean corpuscular volume (MCV), mean corpuscular hemoglobin $(\mathrm{MCH})$ dan mean corpuscular hemoglobin concentration (MCHC), ditemukan mikrositer berjumlah 8 orang, normositer berjumlah 9 orang dan makrositer berjumlah 2 orang ditinjau dari MCV dan 6 pasien hipokromik serta 11 pasien normokromik ditinjau dari $\mathrm{MCH}$.

\section{SIMPULAN}

Prevalensi anemia pada pasien gagal jantung di RSUP Prof. Dr. R. D. Kandou Manado pada tahun 2013 adalah 33,6\%.

Distribusi pasien gagal jantung dengan anemia yang berjenis kelamin perempuan memiliki proporsi yang lebih besar yaitu $33,57 \%$ dibandingkan dengan pasien berjenis kelamin laki-laki yaitu 33,54\% walaupun perbedaannya tidak signifikan.

Pasien dengan kelompok usia lebih dari 64 tahun memiliki proporsi terbesar dibanding dengan kelompok umur lainnya.

Pasien gagal jantung dengan anemia terbanyak menderita anemia ringan 171 (57\%).

\section{DAFTAR PUSTAKA}

1. Go AS, Mozaffarian D, Roger VL, Benjamin EJ, Berry JD, Borden WB, et al. Heart disease and stroke statistics--2013 update: a report from the american heart association. Circulation. 2013;127:199.

2. Laporan Nasional 2013. Riset kesehatan dasar (RISKESDAS) 2013. Badan penelitan dan pengembagan kesehatan. Departemen Kesehatan, Republik Indonesia, Jakarta; Desember 2013.

3. Ezekowitz JA, McAlister FA, Armstrong PW. Anemia is common in heart failure and is associated with poor outcomes. Circulation. 2003;107:223-5.
4. Tang YD, Katz SD. Anemia in chronic heart failure: prevalence, etiology, clinical correlates, and treatment options. Journal of the american heart association. 2006;113: 2454-61.

5. Silverberg DS, Wexler D, Blum M, Keren G, Sheps D, Leibovitch E, et al. The use of subcutaneous erythropoietin and intravenous iron for the treatment of the anemia of severe, resistant congestive heart failure improves cardiac and renal function and functional cardiac class, and markedly reduces hospitalizations. J Am Coll Cardiol. 2000;35:1737-44.

6. Anand IS, Kukowski MA, Rector TS, Florea VG, Glazer RD, Hester A, et al.

Anemia and change in hemoglobin over time related to mortality and morbidity in patients with chronic heart failure: reslts from Val-HeFT. Circulation. 2005;112:1121-7.

7. Silverberg DS, Wexler D, Iaina A. The Importance of Anemia and its Correction in the Management of Severe Congestive Heart Failure. Eur J Heart Fail. 2002;4:681-6.

8. Silverberg DS, Wexler D, Sheps D, Blum M, Keren G, Baruch R, et al. The effect of correction of mild anemia in severe, resistant congestive heart failure using subcutaneous erythropoietin and intravenous iron: a randomized controlled study. J Am Coll Cardiol 2001;37:1775-80.

9. Bakta IM. Pendekatan terhadap pasien anemia. In: Sudoyo AW, Setiyohadi B, Alwi I, Simadibrata M, Setiati S. Buku ajar ilmu penyakit dalam. Edisi ke-5. Jakarta: InternaPublishing; 2010. p. 1109-11.

10. Preventing and controlling anaemia through primary health care: a guide for health administrators and programme managers. Geneva, World Health Organization, 1989. [cited 2015 Jan 28]. Available from: http://www.who.int/nutrition/publicatio ns/micronutrients/anaemia_iron_deficie ncy/9241542497.pdf. 